\title{
ANALISIS USAHATANI JAMUR TIRAM PUTIH (Pleurotus ostreatus) DI KECAMATAN UNGARAN TIMUR KABUPATEN SEMARANG
}

\author{
Sellia Fara Fauziyah"1), Saparto'), Ryantoko Setyo Prayitno ${ }^{3)}$ \\ 1,2,3)STIP Farming Semarang, Jl. PawiyatanLuhur IV/15, BendanDuwur, Semarang. \\ Email :saparto.saparto@gmail.com
}

\begin{abstract}
ABSTRAK
Penelitian ini bertujuan untuk mengetahui pendapatan, kelayakan finansial, dan pengaruh biaya baglog dan tenaga kerja terhadap pendapatan usahatani jamur tiram putih. Penelitian dilaksanakan di Kecamatan Ungaran Timur, Kabupaten Semarang dengan menggunakan metode penelitian deskriptif analisis ex post facto. Penelitian dilakukan dengan cara sensus menggunakan 41 orang petani jamur tiram putih sebagai responden. Metode analisis data yang digunakan: rumus pendapatan; kelayakan finansial (R/C ratio, BEP\& $\mathrm{ROI}$ ). Untuk mengetahui pengaruh biaya baglog dan tenaga kerja terhadap pendapatan menggunakan analisis regresi linier berganda ( $u j i-F$, uji-t dan $\mathrm{R}^{2}$ adj.). Hasil penelitian rata-rata skala usaha \pm 7.539 baglog per periode produksi (3-4 bulan) : 1). Pendapatan $=\mathrm{Rp} .13 .516 .498,-, 2) . \mathrm{R} / \mathrm{C}$ ratio $=2,00, \overline{B E P}(\mathrm{Q})=1.278$ $\mathrm{kg}, \mathrm{BEP}_{(\mathrm{Rp})}=\mathrm{Rp} .5 .823,-/ \mathrm{kg}, \mathrm{ROI}=87,00 \%$. Ada pengaruh yang sangat signifikan dari biaya baglog dan tenaga kerja terhadap pendapatan $(P<1 \%)$. Persamaan Regresi $: \widehat{Y}=-5.541 .231+0,987 X_{1}^{* *}+3,282 X_{2}^{* *}+\varepsilon$, $\mathrm{R}^{2}{ }_{\mathrm{adj}}=0,887$. Usahatani jamur tiram putih menguntungkan, layak secara finansial untuk diusahakan, dan ada pengaruh yang sangat signifikan dari biaya baglog dan tenaga kerja terhadap pendapatan.
\end{abstract}

Kata kunci : Jamur Tiram, Kelayakan, Pendapatan, Usahatani

\section{ABSTRACT}

This study aims to determine the income, financial feasibility and the effect of baglog and labor costs on white oyster mushroom farming income. The research was conducted in East Ungaran Subdistrict, Semarang Regency using the ex post facto analysis descriptive research method. The research was conducted by means of a census using 41 white oyster mushroom farmers as respondents. Data analysis methods used: income formula; financial feasibility ( $R / C$ ratio, BEP \& ROI). To determine the effect of baglog and labor costs on income using multiple linear regression analysis ( $F$-test, $t$-test and R2adj.). The results of the research averaged business scale $+7,539$ baglog per production period (3 - 4 months): 1). Income $=R p .13,516,498,-, 2) . R / C$ ratio $=2.00, B E P(Q)=1.278 \mathrm{~kg}, B E P(R p)=R p .5,823,-/ \mathrm{kg}, R O I=$ $87.00 \%$. There is a very real effect of baglog and labor costs on income $(P<1 \%)$. Regression Equation: $Y^{\wedge}=$ $-5,541,231+0.987 X_{1}^{* *}+3.282 X_{2}^{* *}+\varepsilon, R^{2} a d j=0.887$. White oyster mushroom farming is profitable, financially feasible to run, and there is a very real effect of baglog costs and labor on income.

Keywords: Farming, Feasibility, Income, Oyster Mushrooms

\section{PENDAHULUAN}

Jamur tiram putih (Pleurotus ostreatus) merupakan tanaman bernilai ekonomi, mengan-dung gizi tinggi dan mudah dibudidayakan serta tidak memerlukan lahan yang luas. Direktorat Jenderal Hortikultura (2007) menyatakan bahwa jamur tiram mengandung protein $3,5-4 \%$ dari berat basah atau 19 - 35\% dari berat kering. Sumarmi (2006) menyatakan jamur tiram banyak mengandung vitamin $B, C, D$.
Kandungan mineral makro $\mathrm{K}, \mathrm{P}, \mathrm{Na}, \mathrm{Ca}, \mathrm{Mg}$ mencapai $56-70 \%$ dari total abu. Selain itu mengandung mineral mikro $\mathrm{Zn}$, Fe, Mn, Mo, Co.

Direktorat Jenderal Hortikultura (2007) menyatakan bahwa jamur tiram di Indonesia memiliki luas panen seluas 194,91 ha, dengan produktivitas 52,20 ton/ha dan produksinya mencapai sebesar $10.173,80$ ton. BPS Semarang (2018) menyatakan bahwa Provinsi 
Jawa Tengah memiliki sentra produksi jamur tiram yang cukup berpotensi salah satunya adalah di Kabupaten Semarang. Pada Tahun 2018 produksi jamur tiram di Kabupaten Semarang mencapai 127,380 ton dengan luas panen 4,624 ha.

Kecamatan Ungaran Timur terletak pada ketinggian \pm 294 mdpl, dengan suhu udara rata-rata $21-35^{\circ} \mathrm{C}$. Kondisi ini cocok bagi pertumbuhan jamur tiram. Wilayah ini merupakan salah satu wilayah di Kabupaten Semarang yang banyak mengusahakan budidaya jamur tiram putih.

Informasi awal diperoleh keterangan bahwa biaya yang paling besar dalam usahatani jamur tiram adalah biaya pembelian baglog dan tenaga kerja. Dalam usaha taninya pada umumnya petani belum memperhitungkan secara bisnis. Masih banyak ditemukan sumber daya yang tidak diperhitungkan secara finansial dalam usahanya. Diduga ini karena skala usaha rumah tangga. Hal ini yang mendorong perlunya dilakukan penelitian tentang analisis usahatan ijamur tiram putih di Kecamatan Ungaran Timur, Kabupaten Semarang, khususnya dari aspek pendapatan, kelayakan finansial, serta mengetahui pengaruh biaya baglog dan tenaga kerja terhadap pendapatan.

\section{METODE PENELITIAN}

\subsection{Metode}

Penelitian dilakukan di Kecamatan Ungaran Timur, Kabupaten Semarang. Pemilihan lokasi ditentukan secara purposive, dengan pertimbangan bahwa lokasi tersebut merupakan salah satu sentra produksi jamur tiram.

Penelitian menggunakan metode deskriptif analisis, ex post facto. Metode deskriptif analisis adalah suatu metode yang berfungsi untuk mendeskripsikan atau memberi gambaran terhadap objek yang diteliti melalui data atau sampel yang telah terkumpul sebagaimana mestinya (Sugiyono, 2009).Ex post facto artinya penelitian yang dilakukan setelah suatu kejadian itu terjadi. Bertujuan untuk menemukan penyebab yang memungkinkan perubahan perilaku, gejala atau fenomena yang disebabkan oleh suatu peristiwa, perilaku yang menyebabkan perubahan pada variable bebas secara keseluruhan sudah terjadi (Widarto, 2013).

Kecamatan Ungaran Timur terdapat 41 orang petani yang mengusahakan jamur tiram dengan tingkat skala usahanya antara 1.500 s/d 35.000 baglog. Karena jumlah petani kurang dari 100 orang maka semua digunakan sebagai sampel atau disebut metode sensus (Arikunto, 2006).

Data primer diperoleh dengan melakukan wawancara kepada petani jamurt iram sebagai responden yang dipandu dengan kuesioner; data sekunder diperoleh dengan melakukan observasi langsung ketempat usaha jamurt iram, serta menggunakan data dari lembaga yang terkait.

Data primer meliputi seluruh biaya (biaya tetap dan biaya tidak tetap) yang dikeluarkan untuk produksi jamur tiram. Biaya tetap meliputi biaya penyusutan bangunan, peralatan, pajak, dan rak bambu. Biaya tidak tetap atau biaya variable terdiri dari biaya listrik \& air, sarana jamur, baglog, Zat PengaturTumbuh (ZPT) \& Pestisida, plastik, bahan bakar, dan tenaga kerja. Penerimaan diperoleh dari jumlah produksi dikalikan dengan harga jual.

\subsection{Analisis Data}

\subsubsection{Analisis pendapatan usahatani jamur tiram putih.}

Pendapatan usaha tani jamur tiram putih dihitung dengan rumus (Soekartawi, 1995) :

$$
\begin{aligned}
& \mathrm{Pd}=\mathrm{TR}-\mathrm{TC} \\
& \mathrm{TR}=\mathrm{y} . \mathrm{Py} \\
& \mathrm{TC}=\mathrm{FC}+\mathrm{VC}
\end{aligned}
$$

Keterangan :

$$
\begin{aligned}
& \mathrm{Pd}=\text { Pendapatan }(\mathrm{Rp}) \\
& \mathrm{TR}=\text { Total Revenue/Penerimaan }(\mathrm{Rp}) \\
& \mathrm{TC}=\text { Total Cost/Total Biaya }(\mathrm{Rp}) \\
& \mathrm{FC}=\text { FixedCost/BiayaTetap }(\mathrm{Rp}) \\
& \mathrm{VC}=\text { Variable Cost/BiayaTidakTetap }
\end{aligned}
$$


Kriteria :

Jika $\mathrm{Pd}>0$, maka usaha jamur tiram menguntungkan.

Jika $\mathrm{Pd}=0$, maka usaha jamur tiram mencapai titik impas.

Jika $P d<0$, maka usaha jamur tiram mengalami kerugian.

\subsubsection{Analisis kelayakan finansial usahatani}

\section{jamur tiram putih.}

Analisis Revenue Cost Ratio (RCR) menggunakan rumus matematis sebagai berikut :

$$
\mathrm{RCR}=\frac{\text { Penerimaan }}{\text { Total Biaya Produksi }}
$$

Kriteria :

$\mathrm{RCR}>1$, usahatani layak diusahakan

$\mathrm{RCR}<1$, usahatani tidak layak

$\mathrm{RCR}=1$, usahatani impas

Analisis Break Even Point atau BEP menggunakan rumus sebagai berikut.

Kriteria :

$\mathrm{BEP}_{(\mathrm{Q})}=\frac{\text { Total Biaya Produksi }}{\text { Harga }}$

BEP (Q) > produksi, maka usahatani tidak

layak untuk diusahakan.

BEP $(\mathrm{Q})<$ produksi, maka usahatani layak

untuk diusahakan.

BEP Harga atau BEP ${ }_{(\mathrm{Rp})}$, untuk menganalisis harga minimum agar usahatani tidak mengalami kerugian atau impas.

Kriteria :

$$
\mathrm{BEP}_{(\mathrm{Rp})}=\frac{\text { Total Biaya Produksi }}{\text { Volume Produksi }}
$$

BEP $_{(\mathrm{Rp})}>$ harga pasar, usahatani tidak layak untuk diusahakan

$\mathrm{BEP}_{(\mathrm{Rp})}<$ harga pasar, usahatani layak untuk diusahakan

Untuk analisis Return of Investment atau ROI menggunakan rumus matematis sebagai berikut :

$$
\mathrm{ROI}=\frac{\text { Pendapatan Bersih }}{\text { Total Biaya Produksi }} \times 100 \%
$$

Kriteria :

$\mathrm{ROI}<i$ (tingkat suku bunga bank yang

berlaku), maka usahatani tersebut

tidak

layak untuk diusahakan.

$\mathrm{ROI}>i$ (tingkat suku bunga Bank yang

berlaku), maka usahatani

tersebut layak untuk diusahakan

(Sumarjo, 2004)

\subsubsection{Analisis regresi linier berganda}

Analisis besar pengaruh biaya baglog dan tenaga kerja terhadap pendapatan usahatani jamur tiram putih digunakan analisis regresi linier berganda. Perhitungan dengan menggunakan bantuan SPSS 16.0 for windows. Model persamaan Regresi Linier Berganda menggunakan rumus:

$$
\widehat{Y}=a+b_{1} X_{1}+b_{2} X_{2}+\varepsilon
$$

Keterangan :

$$
\begin{aligned}
& \widehat{Y}=\text { Prediksi pendapatan }(R p) \\
& a=\text { Konstanta }(R p) \\
& b_{1}-b_{2}=\text { Koefisien regresi } \\
& X_{1}=\text { Biaya baglog }(R p) \\
& X_{2}=\text { Biaya tenaga kerja }(R p) \\
& \varepsilon=\text { Error/galat }
\end{aligned}
$$

\section{HASIL DAN PEMBAHASAN}

\subsection{Analisis Pendapatan Usahatani Jamur}

\section{Tiram Putih}

Perhitungan biaya dan penerimaan usahatani jamur tiram dihitung dalam satu periode produksi (3-4 bulan). Rekapitulasi data terkait biaya tetap, biaya tidak tetap, total biaya produksi, penerimaan dan pendapatan disajikan pada Tabel 1.

Tabel 1. menyatakan bahwa penggunakan baglog sebanyak 7,539 buah selama periode produksi $3-4$ bulan diperoleh produksi sebanyak $2.565 \mathrm{~kg}$ jamur tiram. Harga jual Rp.10.500,-/kg maka diperoleh penerimaan sebesar Rp. 26.937.007,-. Total 
biaya produksi yang dikeluarkan rata-rata sebesarRp. 13.420.504,-. Dengan demikian diperoleh pendapatan sebesarRp. 13.516.498,- atau Rp. 1.793,-/baglog.

Tingkat produktivitasnya sebesar : 2.565 $\mathrm{kg}: 7.539$ baglog $=0,340 \mathrm{~kg}$ jamur tiram/baglog. Hasil penelitian ini lebih tinggi dibanding hasil penelitian Shintia dan Amalia (2017) serta Wijaya et al. (2020). Hasil penelitian Shintia dan Amalia (2017) masa produksi 4 bulan yang mendapatkan tingkat produktivitas sebesar : $1.200 \mathrm{~kg}: 5.000$ baglog $=0,240 \mathrm{~kg}$ jamur tiram $/$ baglog. Lebih lanjut penelitian Wijaya et al. (2020) mendapatkan hasil rata-rata produktivitas jamur tiram selama tahun 2014-2018 sebesar 1,6 ons per musim. Namun demikian setelah dilakukan penerapan inovasi teknologi bangker pintar produksi meningkat menjadi 0,325 kg/baglog. Akan tetapi tingkat produktivitas hasil penelitian ini masih lebih rendah dibanding hasil penelitian Saputra et al. (2015) yang mencapai : 0,598 kg/baglog. Hanya saja hasil produksi tersebut dilakukan sampai 5 bulan lamanya.

Perbedaan tingkat produktivitas jamur disebabkan oleh beberapa fakto rantara lain, jenis dan komposisi media tumbuh jamur atau substratnya, kelembapan, bibit jamur, teknologi dll. Sesuai pernyataan Puspitasari et al.,(2017) bahwa factor produksi yang berpengaruh terhadap produksi jamur tiram adalah luas lahan, serbuk kayu, bekatul dan tenaga kerja, sedangkan factor produks ibibit dan kapur tidak berpengaruh nyata terhadap produksi jamur tiram. Ditambahkan oleh Ding et al. (2019) bahwa media tumbuh berpengaruh berbeda nyata terhadap waktu awal tumbuh miselium, waktu miselium memenuhi media tumbuh, awal munculnya tubuh buah, jumlah tubuh buah, lebar tudung maksimal, Panjang tangkai tubuh buah, dan berat tubuh buah jamur tiram. Pemberianpupuk TSP berpengaruh berbeda sangat nyata terhadap waktu awal tumbuh miselium, waktu miselium memenuhi media tumbuh, awal munculnya tubuh buah, jumlah tubuh buah, lebar tudung maksimal, Panjang tangkai tubuh buah, dan berat tubuh buah jamur.

Penelitian ini memperoleh pendapatan bersih sebesarRp. 13.516.498,-. Apabila dihitung per baglog maka diperoleh pendapatan bersih sebesar Rp. 1.793,/baglog.Pendapatan ini lebih besar bila dibanding yang diperoleh Wijaya et al. (2020) sebesar Rp.607.5,-l baglog. Hal ini disebabkan karena tingkat produk-tivitasnya $0,340 \mathrm{~kg}$ jamur/baglog/periode sedangkan Wijaya et al. (2020) sebesar 0,160 $\mathrm{kg} / \mathrm{bag}$ log/periodeproduksi. Pendapatan hasil penelitian ini lebih rendah dibanding penelitian Zikri et al. (2015) sebesar Rp. 4.198,-/baglog; produktivitasnya sebesar $0,500 \mathrm{~kg} / \mathrm{baglog}$ dengan harga jual Rp. 30.600,-/kg jamur.Hal ini disebabkan karena perbedaan tingkat produktivitas jamur dan harga jual jamur.

\subsection{Analisis Kelayakan Finansial Usahatani Jamur}

Kelayakan usaha dapat diartikan bahwa usaha yang dijalankan akan memberikan keuntunganfinansial dan non finansial sesuai dengan tujuan yang diinginkan.Usaha tani jamur tiram dikatakan efesien apabila usaha tani tersebut secara ekonomis menguntungkan serta biaya yang dikeluarkan selama proses usaha tani lebih kecil dari penjualan jamur tiram yang diterima. Dalam hal ini, penggunaan biaya pada usaha tani jamur tiram dikatakan efesien apabila nilai $\mathrm{R} / \mathrm{C}$ rasio lebih dari satu dan sebaliknya apabila nilai $R / C$ rasio kurang dari satu maka usahatani jamur tiram dikatakan tidak efesien. Rekapitulasi perhitungan tentang kelayakan finansial usaha tani jamur tiram disajikan pada Tabel 2.

Dari Tabel 2, diperoleh nilai $\mathrm{R} / \mathrm{C}=2,0$; $\mathrm{BEP}_{(\mathrm{Q})}=1,278,1 \mathrm{~kg}$ (sedangkan produksi riil = $2,565 \mathrm{~kg}) ; \quad \mathrm{BEP}_{(\mathrm{Rp})}=\mathrm{Rp} . \quad 5.232,-\mathrm{kg}$ (sedangkan harga riil $=$ Rp. 10.500,-); ROI sebesar 100,71 \% selama 3-4 bulanataulebihdari 25\%/ bulan (sehingga nilainya > suku bunga yang berlaku). Dengan 
demikian maka dapat dikatakan bahwa usahatani jamur tiram putih di lokasi penelitian memperoleh keuntungan dan layak secara finansial untuk diusahakan.

Nilai $\mathrm{R} / \mathrm{C}=2,00$ ini lebih tinggi dibanding Setiawan (2011) R/C=1,29; Zikri et al. (2015) $\mathrm{R} / \mathrm{C}=1,46$. Namun hasil penelitian ini lebih rendah dibanding Saputra et al.(2015) $\mathrm{R} / \mathrm{C}=4,25$; Shintia dan Amalia (2020) $\mathrm{R} / \mathrm{C}=2,04$. Perbedaan nilai $\mathrm{R} / \mathrm{C}$ ini tergantung pada jumlah produksi dan harga jual, dan biaya lainnya. Harga jamur tiram pada Shintia dan Amalia (2020) Rp. 30.000,-/kg, sedangkan hasil penelitian sebesar $R p$. $10.500,-/ \mathrm{kg}$. Sebaliknya pada Zikri et al. (2015), walupun mendapatkan harga jual tinggi namun biaya produksi yang sangat besar maka memperoleh niali $\mathrm{R} / \mathrm{C}$ yang rendah. Hal ini sejalan dengan pernyataan Soekartawi (1990) menyatakan bahwa tingkat pendapatan petani secara umum dipengaruhi oleh beberapa komponen yaitu jumlah produksi, harga jual, dan biaya-biaya yang dikeluarkan petani dalam usaha pertaniannya. Besarnya pendapatan yang akan diperoleh tergantung dari beberapa faktor yang mempengaruhinya seperti luas lahan, tingkat produksi, dan efisiensi penggunaan tenaga kerja. Harga dan produktivitas merupakan sumber dari faktor ketidakpastian, sehingga bila harga dan produksi berubah maka pendapatan yang diterima petani juga berubah.

Harga pasar merupakan hal yang sulit dikendalikan oleh produsen jamur tiram. Hal ini dikarenakan jamur tiram merupakan produk yang diproduksi oleh banyak petani (pasar bebas), sehingga harga jual jamur tiram akan terjadi pada saat tercapai titik keseimbangan antara permintaan dengan penawaran.

Demikian juga kelayakan finansial usahatani jamur tiram putih hasil penlitian berdasarkan nilai BEP dan ROI menunjukkan bahwa usahatani tersebut layak secara finansial untuk diusahakan. Ada perbedaan nilai $\mathrm{ROI}$ hasil penelitian ini dengan penelitian sebelumnya. Nilai ROI hasil penelitian sebesar $100,71 \%$, relative lebih rendah bila dibandingkan hasil penelitian Shintia dan Amalia (2020) sebesar 104,49\%, dan Saputra et al. (2015) sebesar 325,08\%. Hal ini diduga disebabkan perbedaan harga jual jamur tiram yang lebih tinggi, dan disebabkan karena biaya tenaga kerja yang berbeda. Perbedaan dengan Saputraet al. (2015) adalah pada komponen biaya tenaga kerja sangat berbeda, dimana biaya tenaga kerja menjadi sangat efisien dengan cara diborongkan dalam pembuatan baglog. Pada umumnya komponen biaya tenaga kerja pada usahatani jamur tiram relative cukup besar dibanding komponen biaya variable lainnya.

\subsection{Analisis Regresi Linier Berganda Usahatani Jamur Tiram}

Dari aspek budidaya, produktivitas usahatani jamur tiram dapat mengalami peningkatan maupun penurunan jumlah produksi, disebabkan oleh kuantitas dan/atau kualitas penggunaan factor produksi yang kurang tepat. Penggunaan factor produksi merupakan salah satu kunci utama dalam produksi usahatani jamur tiram. Jika penggunaan factor produksi tidak tepat maka akan menyebabkan penurunan produksi dalam usahatani jamur tiram.

Dari aspek finansial, masing masing komponen biaya khususnya komponen biaya tidak tetap akan mempengaruhi pendapatan usahatani jamur tiram. Penerimaan tergantung pada tingkat produktivitas dan harga jual. Dari Tabel 1. menunjukkan bahwa komponen biaya baglog dan tenaga kerja menduduki persentasi biaya produksi yang tertinggi. Biaya baglog mencapai $67,41 \%$, dan biaya tenaga kerja mencapai $23,00 \%$. Shintia dan Amalia (2017) biaya baglog 31,65\%, tenaga kerja 47,71\%; Anggraeni et al. (2021) melaporkan biaya baglog sebesar $64,71 \%$, dan biaya tenaga kerja sebesar $25,21 \%$. Mengingat kedua komponen ini merupakan biaya terbesar dalam produksi jamur tiram, 
maka perlu dipelajari tentang pengaruh biaya baglog dan tenaga kerja terhadap pendapatan usahatani jamur tiram.

Untuk mengetahui pengaruh biaya baglog dan tenaga kerja terhadap pendapatan digunakan analisis regresi linear berganda, sebagai variable bebas adalah :biaya baglog (X1) dan biaya tenaga kerja $\left(\mathrm{X}_{2}\right)$, sedangkan variable tergantungnya adalahpendapatan (Y). Hasil olah data disajikan pada Tabel 3.

Dari Tabel 3. Dapat dibuat model persamaan regresi linier berganda sebagai berikut:

$$
\hat{Y}=-5 \cdot 541 \cdot 231^{*}+0,987 X_{1}^{* *}+3,282 X_{2}^{* *}+\varepsilon
$$

Hasil Uji-F pada Tabel 3. Menunjukkan angka signifikasinya sebesar $0,000(P<0,01)$ maka dapat dinyatakan bahwa faktor biaya baglog, dan tenaga kerja secara simultan berpengaruh sangat signifikan terhadap pendapatan usahatani jamur tiram putih. Artinya bahwa biaya baglog dan biaya tenaga kerja secara serempak atau bersama-sama berpengaruh sangat signifikan terhadap pendapatan usahatani jamur tiram. Untuk ini perlu petani memperhatikan kedua komponen biaya tersebut dalam usahatani jamur tiram, agar diperoleh pendapatan yang optimal.

Selanjutnya dilakukan uji-t koefisien regresi secara parsial darimasing-masing koefisien tersebut apakah berpengaruh sangat signifikan atau tidak. Secara parsial pengaruh faktor-faktor biaya baglog dan biaya tenaga kerja $\left(\mathrm{X}_{1}\right.$, dan $\left.\mathrm{X}_{2}\right)$ terhadap pendapatan (Y) pada usahatani jamur tiram dapat dijelaskan sebagai berikut:

Nilai koefisien regresi $b_{1}=+0,987$ artinya jika biaya baglog $\left(\mathrm{X}_{1}\right)$ ditambah satusatuan biaya $(\mathrm{Rp})$ maka variabel pendapatan (Y) akan naik sebesar 0,987satuan (Rp), apabila satuan tenaga kerja tetap. Sedangkan nilai signifikannya $=0,000$ artinya biayabaglog berpengaruh sangat signifikan terhadap pendapatan usahatani jamurtiram, apabila baglog ditambah pendapatan akan mengalami kenaikan. Ini ditunjukkan koefisien regresi biaya baglog yang memiliki nilai positif (+).Hal ini menunjukkan bahwa penggunaan biaya baglog sebaiknya ditambah (jumlah baglog) agar pendapatan dapat semakin meningkat.

Nilai koefisien regresi $b_{2}=+3,282$ artinya jika biaya tenaga kerja $\left(\mathrm{X}_{2}\right)$ ditambah satusatuan (Rp) maka variabel pendapatan (Y) akan bertambah sebesar 3,282satuan (Rp), apabila satuan biaya baglog tetap. Sedangkan nilaisignifikan $=0,004$ artinya biaya tenaga kerja berpengaruh sangat signifikan terhadap pendapatan. Dapat dikatakan bahwa biaya tenaga kerja dalam penelitian ini masih bias dioptimalkan lagi dengan menambah, karena koefisien menunjukkan nilai positif $(+)$. Kualitas tenaga kerja perlu ditingkatkan agar produktifitas tenaga kerja dapat meningkat. Kualitas tenaga kerja ini berkaitan dengan besar biaya tenaga kerja. Semakin berkualitas atau semakin tinggi produktivitasnya maka akan semakin mahal biaya tenaga kerjanya.

Untuk mengetahui seberapa besar biaya baglog dan biaya tenaga kerja berpengaruh terhadap pendapatan usahatani jamur tiram dapat dilihat pada seberapa besar nilai Koefisien Determinasinya $\left(R^{2}{ }_{a d j}\right)$. Berdasarkan hasil olah data penelitian diperoleh koefisien determinasi yang disesuaikan/adjusted $R$ square $\left(R^{2}{ }_{\text {adj }}\right)=0,887$ $\left(0 \leq R^{2} \leq 1\right)$, artinya kontribusi biaya produksi biaya baglog dan tenaga kerja terhadap pendapatan sebesar $88,7 \%$ dan sisanya sebesar $12,3 \%$ dipengaruhi variabel bebas lainnya yang tidak masuk dalam penelitian, misalnya faktor lingkungan dan harga jual jamur tiram pada waktu tertentu. Semakin besar nilai $R^{2}$ adj ini akan memperoleh persamaan regresi linier berganda yang semakin baik untuk digunakan sebagai prediktor. Karena dalam penelitian ini menghasilkan $R^{2}$ adj sebesar 88,7\% maka persamaan regresi linier berganda dalam penelitian ini dapat digunakan sebagai prediktoryang sangat baik terhadap pendapatan usahatani jamur tiram. 


\section{SIMPULAN}

Dari hasil dan pembahasan maka dapat ditarik kesimpulan : Usahatani jamur tiram putih di Kecamatan Ungaran Timur Kabupaten Semarang menguntungkan, dan layak secara finansial untuk diusahakan, serta ada pengaruh dari biaya baglog dan tenaga kerja terhadap pendapatan.

\section{DAFTAR PUSTAKA}

Anggraeni, R. ,Subeni, dan K. Umam. 2012. Analisis Pendapatan, Keuntungan, dan Kelayakan Usaha Jamur Tiram di Kabupaten Sleman. JurnalAgro UPY, $6(1): 1-12$.

Arikunto, S. 2006. Prosedur Penelitian Suatu Pendekatan Praktek. Jakarta : Rineka Cipta.

Badan Pusat Statistik [BPS] Kabupaten Semarang. 2018. Statistik Pertanian Hortikultura Kabupaten Semarang 2017 - 2018 : 29.

Ding, F. J., H. Syahfari, dan M. Napitupulu. 2019. Pengaruh Media Tumbuh dan Pemberian Pupuk TSP pada BudidayaJamurTiramPutih (Pleurotus ostreatus). Jurnal AGRIFOR, 18(1): 97-108.

Direktorat Jenderal Hortikultura (2007) Rujukan Pengembangan Agribisnis Hortikultura TA2007, Departemen Pertanian.

Puspitasari, V. D., E. Prasetyo, dan H. Setiyawan. 2017. Analisis Efisiensi Ekonomi Penggunaan Faktor-faktor Produksi pada Usaha Jamur Tiram di Desa Genting Kecamatan Jambu Kabupaten Semarang. AGRISOCIONOMIS, Jurnal Sosial Ekonomi Pertanian. 1 (1): 63-71.
Saputra, A. S., T. D. Hapsari, dan J. Januar. Analisis Efisiensi Biaya Usahatani Jamur Tiram (Pleurotus sp) dan Pemasarannya di Kabupaten Jember. Agritop Jurnal IImu-IImuPertanian. 13 (2) : 195 - 206.

Setiawan, E., 2011. Analisis Usahatani Jamur Tiram (Pleurotur ostreatus) di Kabupaten Sukoharjo. Skripsi. Fak. Pertanian, UNS Surakarta.

Shintia, R. D., dan Amalia. 2017. Analisis Usahatani Jamur Tiram Putih (Pleurotus ostreatus) di Kelurahan Simpang BaruKecamatan Tampan Kota Pekan Baru. Jurnal Ilmiah Pertanian, 13(2): 38 - 49.

Soekartawi. 1990. Teori Ekonomi Produksi dengan Pokok Bahasan Analisis Fungsi Cobb-Douglas. Jakarta: Rajawali Press.

Soekartawi, 1995. Analisis Usahatani. UI. Jakarta.

Sugiyono, 2009. Metode Penelitian Kuantitatif, Kualitatif dan $R \& D$. Bandung Alfabeta.

Sumardjo, 2004. Kemitraan Agribisnis. Jakarta:

Penebar Swadaya.

Sumarmi, 2006. Botani dan Tinjauan Gizi Jamur Tiram Putih. Jurnal Inovasi Pertanian. 4(2): 124-130.

Widarto, 2013. Penelitian Ex Post Facto. Disampaikan pada kegiatan Pelatihan Metodologi Penlitian Pendidikan di Fak Teknik Univ. Negeri Yogyakarta. Tgl. 27-28 Juni 2013. 
Fauziah, et al. 2021

Vol. 5, No. 2, 2021

Wijaya, O., A. Darmawan, Marbudi, M. N. D.

Dzikrulloh, dan M. L. Hakim. 2020.

Peningkatan Produktivitas Usahatani Jamur Tiram Melalui Penerapan Inovasi Teknologi Bangker Pintar di Desa Balecatur, Kecamatan Gamping Kabupaten Sleman. Agrokreatif. Jurnal IImiah Pengabdian kepada Masyarakat. 6(2):105 - 111.

Zikri, A. R., S. Khaswarina, dan E. Maharani. 2015. Analisa Usaha dan Pemasaran Jamur Tiram Putih (Pleurotus ostreatus) StudiKasus di Kelurahan Tangkerang Timur Kecamatan Tenayan Raya Kota Pekanbaru. JomFaperta, 2(2). 
Agrisaintifika

Tabel1. Rata-rata Biaya Produksi, Penerimaan dan Pendapatan Usahatani Jamur Tiram per Periode Produksiper 7.539 Baglog di Kecamatan Ungaran Timur Kabupaten Semarang.

\begin{tabular}{|c|c|c|c|}
\hline No. & Uraian & Jumlah (Rp) & $\begin{array}{c}\text { Persentasi dari } \\
\text { Biaya Produksi (\%) }\end{array}$ \\
\hline \multirow[t]{6}{*}{1} & Biaya Tetap & & \\
\hline & a. Penyusutan bangunan & 64.537 & 0,48 \\
\hline & b. Penyusutan peralatan & 48.083 & 0,36 \\
\hline & c. Pajak & 148.280 & 1,11 \\
\hline & d. Rak bambu & 63.790 & 0,47 \\
\hline & Total Biaya Tetap & 324.690 & 2,42 \\
\hline \multirow[t]{9}{*}{2} & Biaya Tidak Tetap & & \\
\hline & a. Listrik \& air & 190.585 & 1,42 \\
\hline & b. Sarana jamur & 5.731 & 0,04 \\
\hline & c. Baglog & 9.046 .829 & 67,41 \\
\hline & d. ZPT \& pestisida & 167.304 & 1,25 \\
\hline & e. Plastik packing & 432.219 & 3,22 \\
\hline & f. Bahan bakar & 166.317 & 1,24 \\
\hline & g. Tenaga kerja & 3.086 .829 & 23,00 \\
\hline & Total Biaya Tidak Tetap & 13.095 .814 & 97,58 \\
\hline 3 & Total Biaya Produksi & 13.420 .504 & 100,00 \\
\hline \multirow[t]{4}{*}{4} & Penerimaan : 7.539 baglog & & \\
\hline & a. Produksi $(\mathrm{kg})$ & 2.565 & \\
\hline & b. Harga $(\mathrm{Rp} / \mathrm{kg})$ & 10.500 & \\
\hline & Total Penerimaan & 26.937.007 & \\
\hline 5 & Pendapatan & 13.516 .498 & \\
\hline
\end{tabular}

Sumber : Data Primer diolahTahun 2020.

Tabel 2. Hasil Rata-rata Perhitungan Kelayakan Finansial Usahatani Jamur Tiram Putih Dalam Satu Periode Produksi per 7.539 Baglog

\begin{tabular}{clr}
\hline No & \multicolumn{1}{c}{ Uraian } & Nilai \\
\hline 1 & Total Produksi Jamur (kg) & 2.565 \\
2 & Harga Jual Jamur (Rp/kg) & 10.500 \\
3 & Total Penerimaan (Rp) & 26.937 .007 \\
4 & Total BiayaProduksi (Rp) & 13.420 .504 \\
5 & Pendapatan (Rp) & 13.516 .498 \\
6 & R/C & 2,00 \\
7 & BEP Q $(\mathrm{kg})$ & $1.278,1$ \\
8 & BEP $(\mathrm{Rp})$ & 5.232 \\
9 & ROI $(\%)$ & 100,71 \\
\hline
\end{tabular}

Sumber : Data Primer Diolah (2020)

Tabel 3. Rekapitulasi Analisis Regresi Berganda Usahatani Jamur Tiram.

\begin{tabular}{clrl}
\hline No. & \multicolumn{1}{c}{ Uraian } & \multicolumn{1}{c}{ Nilai } & Signifikans i \\
\hline 1 & Uji-F & 157,322 & $\left.{ }^{* *}\right)$ Sangat sig. \\
2 & Koef. Korelasi $(\mathrm{R})$ & 0,945 & \\
3 & Koef. Det. $\left(\mathrm{R}^{2}\right)$ & 0,892 & \\
4 & Koef. Det Adjust $\left(\mathrm{R}_{\text {Adjst }}{ }^{2}\right)$ & 0,887 & \\
5 & Konstanta $(\mathrm{a})$ & -5.541 .231 & $\left.{ }^{*}\right)$ Sig. \\
6 & Koef. Biaya Baglog $\left(\mathrm{X}_{1}\right)$ & 0,987 & $\left.{ }^{*}\right)$ Sangat sig. \\
7 & Koef. Biaya Tenaga Kerja $\left(\mathrm{X}_{2}\right)$ & 3,282 & $\left.{ }^{*}\right)$ Sangat sig. \\
\hline
\end{tabular}

Sumber : Data Primer Diolah (2020) 